\title{
Lactobacillus acidophilus LA 1 binds to cultured human intestinal cell lines and inhibits cell attachment and cell invasion by enterovirulent bacteria
}

M F Bernet, D Brassart, J R Neeser, A L Servin

\begin{abstract}
Four human Lactobacillus acidophilus strains were tested for their ability to adhere onto human enterocyte like Caco- 2 cells in culture. The LA 1 strain exhibited a high calcium independent adhesive property. This adhesion onto Caco-2 cells required a proteinaceous adhesion promoting factor, which was present in the spent bacterial broth culture supernatant. LA 1 strain also strongly bound to the mucus secreted by the homogeneous cultured human goblet cell line HT29-MTX. The inhibitory effect of LA 1 organisms against Caco-2 cell adhesion and cell invasion by a large variety of diarrhoeagenic bacteria was investigated. As a result, the following dose dependent inhibitions were obtained: (a) against the cell association of enterotoxigenic, diffusely adhering and enteropathogenic Escherichia coli, and Salmonella typhimurium; (b) against the cell invasion by enteropathogenic Eschericha coli, Yersinia pseudotuberculosis, and Salmonella typhimurium. Incubations of $L$ acidophilus LA 1 before and together with enterovirulent $\boldsymbol{E}$ coli were more effective than incubation after infection by $\boldsymbol{E}$ coli.

(Gut 1994; 35: 483-489)
\end{abstract}

Lactobacilli have been largely introduced into several fermented dairy products. As recently underlined by Klaenhammer, ${ }^{1}$ lactobacilli strains with well defined properties should be scientifically selected and characterised for specific use in commercial preparations. One of these properties should be the ability to adhere to mucosal surfaces, which could confer a competitive advantage, important for bacterial maintenance in the human gastrointestinal tract. Recent reports show that selected strains, such as Lactobacillus casei $\mathrm{GG},{ }^{2}$ Lactobacillus acidophilus BG2FO4, ${ }^{3-5}$ and LB $^{6}$ express adhesive factors, which permit interactions with human enterocyte like cells. Another desirable effect is a positive role of exogenous lactobacilli in prevention and treatment of gastrointestinal disorders. There is numerous evidence showing such nutritional and therapeutic benefits of lactobacilli. ${ }^{78}$ To explain this effect, several authors suggested that exogenous lactobacilli could exert a 'barrier effect' against pathogens as does the indigenous microflora. ${ }^{78}$

The aim of this study was to examine the adhesion of lactobacilli of human origin to human intestinal cells. For this purpose we used the enterocyte like Caco- 2 cell line, ${ }^{910}$ which displays typical features of enterocytic intestinal cells. ${ }^{11}{ }^{12}$ Bacterial attachment to the intestinal cell surface was characterised by electron microscopic examination and by quantitative determination. The mechanism through which an adherent $L$ acidophilus strain interacts with Caco- 2 cells was investigated. Moreover, it is well known that the polarised Caco- 2 cell line can mimic the conditions in vivo where infection occurs, after cell association of enterotoxigenic bacteria ${ }^{13-16}$ and cell invasion by enterovirulent bacteria $^{17-20}$ and rotavirus. ${ }^{21}$ Consequently, we examined the inhibition of cell association and cell invasion of pathogens participating in infant ${ }^{22}$ and travellers' diarrhoea ${ }^{23}$ by adhering $L$ acidophilus.

\section{Methods}

BACTERIALSTRAINS, GROWTHCONDITIONS,AND RADIOLABELLING

Lactobacillus acidophilus LA 1, LA 3, LA 10, and LA 18 strains (Nestec collection, Lausanne, Switzerland) were grown in anaerobic conditions (Gaspack $\mathrm{H}_{2}+\mathrm{CO}_{2}$ ) in De Man, Rogosa, Sharpe (MRS) broth (Biokar, Pantin, France) $2 \times 24$ hours at $37^{\circ} \mathrm{C}$ before adhesion assay.

The enterovirulent $E$ scherichia coli strains used in this study were the enterotoxigenic $E$ coli (ETEC) H10407 expressing the CFA/I adhesive factor, ${ }^{24}$ the enteropathogenic $E$ coli (EPEC) JPN15 [pMAR7] $\left(\mathrm{EAF}^{+}\right.$ea $^{+}$) (Professor J B Kaper, Center for Vaccine Development, University of Maryland, USA) ${ }^{18}$ the diffusely adhering $E$ coli (DAEC) C-1845, which belongs to the uropathogenic family (Dr S Bilge, Washington University, Seattle, USA), ${ }^{25} 26$ Yersinia pseudotuberculosis YPIII [pYV ${ }^{-}$(inv $\left.{ }^{+}\right)$(Dr M Simonet, Faculté Necker-Enfants Malades, Paris, France), ${ }^{27}$ and Salmonella typhimurium SL 1344 (Professor B A D Stocker, Stanford, California). ${ }^{17}$

Before adherence assays, ETEC, and DAEC strains were grown on CFA-agar containing 1\% casamino acids (Difco Laboratories, Detroit, USA), $0 \cdot 15 \%$ yeast extract, $0 \cdot 005 \%$ magnesium sulphate, and $0.0005 \%$ manganese chloride in $2 \%$ agar for 18 hours at $37^{\circ} \mathrm{C}$. EPEC bacteria were cultured at $37^{\circ} \mathrm{C}$ for 24 hours in luria broth with $200 \mu \mathrm{g} / \mathrm{ml}$ ampicillin. S typhimurium was cultured at $37^{\circ} \mathrm{C}$ for 18 hours in luria broth. $Y$ pseudotuberculosis was cultured 18 hours at $28^{\circ} \mathrm{C}$ in luria broth.

For radiolabelling, ETEC, DAEC, and EPEC bacteria were subcultured twice at $37^{\circ} \mathrm{C}$ for 24 
hours in luria broth. They were metabolically labelled by the addition of ${ }^{14} \mathrm{C}$-acetic acid (Amersham, UK (94 mCi/mmol); $100 \mu \mathrm{Ci} / 10 \mathrm{ml}$ tube). Before radiolabelling, $S$ typhimurium was cultured for four hours in luria broth and $Y$ pseudotuberculosis was cultured for 18 hours in trypticase soja broth; and for radiolabelling the bacteria were subcultured at $37^{\circ} \mathrm{C}$ for 45 minutes in methionine medium (Difco) with ${ }^{35} \mathrm{~S}$-methionine (Amersham, $1000 \mathrm{Ci} / \mathrm{mmol}, 20 \mu \mathrm{Ci} / \mathrm{ml}$ ).

\section{CELL CULTURE}

Enterocyte like Caco- 2 cells ${ }^{9}$ were obtained from Dr Jorgen Fogh (Sloan Kettering Memorial Cancer Center, Rye, NY, USA). The homogeneous mucus secreting subpopulation of HT29-MTX cells ${ }^{28}$ was obtained from Dr A Zweibaum (Unité 178, Institut National de la Santé et de la Recherche Médicale, Villejuif, France).

Cells were routinely grown in Dulbecco modified Eagle's minimal essential medium $(25 \mathrm{mM}$ glucose)(Eurobio, Paris, France), supplemented with $10 \%$ (HT29-MTX) or $20 \%$ (Caco-2) inactivated $\left(30 \mathrm{~min} ; 56^{\circ} \mathrm{C}\right)$ fetal calf serum (Boehringer, Mannheim, Germany), and 1\% non-essential amino acids (Caco-2). For adhesion assay, monolayers of Caco-2 cells and HT29MTX cells were prepared on glass coverslips, which were placed in six well Corning tissue culture plates (Corning Glass Works, Corning, NY, USA). For inhibition of cell association and cell invasion of pathogens, monolayers of Caco-2 cells were prepared in 20 four well tissue culture plates (Corning Glass Works). Cells were seeded at a concentration of $2 \times 10^{4}$ (HT29-MTX) and $1.4 \times 10^{4}\left(\right.$ Caco-2) cells $/ \mathrm{cm}^{2}$. Maintenance of the cells and all experiments were carried out at $37^{\circ} \mathrm{C}$ in a $10 \% \mathrm{CO}_{2} / 90 \%$ air atmosphere. The culture medium was changed daily. Mucus secreting HT29-MTX and Caco-2 cells were used between 20-40 and 60-90 cell passages, respectively. Cells were used for adherence assays at late postconfluence - that is, after 15 days (Caco-2) and 20 days (HT29-MTX) in culture.

\section{ADHERENCE ASSAY}

The adherence of $L$ acidophilus strains to Caco-2 and HT29-MTX cells was examined as described previously for the $L$ acidophilus strain LB and the $L$ acidophilus strain BG2FO4 adhesion assay. ${ }^{56}$ Briefly, the Caco-2 and HT-29 monolayers, prepared on glass coverslips, which were placed in six well Corning tissue culture plates (Corning Glass Works), were washed twice with phosphate buffered saline. $L$ acidophilus $\left(1 \mathrm{ml}, 4 \times 10^{8}\right.$ bacteria/ml) in spent culture supernatant, treated supernatant or fresh MRS broth were added to 1 $\mathrm{ml}$ of the cell line culture medium. This suspension $(2 \mathrm{ml})$ was added to each well of the tissue culture plate and the plate incubated at $37^{\circ} \mathrm{C}$ in $10 \% \mathrm{CO}_{2} / 90 \%$ air. After one hour of incubation, the monolayers were washed five times with sterile phosphate buffered saline, fixed with methanol, stained with Gram stain, and examined microscopically. Each adherence assay was conducted in triplicate over three successive passages of intestinal cells. For each monolayer on a glass coverslip, the number of adherent bacteria was evaluated in 20 random microscopic areas. Adhesion were evaluated by two different technicians to eliminate bias.

\section{PHYSICAL AND CHEMICAL TREATMENTS OF} BACTERIA AND SPENT CULTURE SUPERNATANT

To characterise the bacterial determinants participating in $L$ acidophilus adhesion, bacteria with spent broth culture supernatant or spent broth culture supernatant alone were subjected to different treatments, as previously described. ${ }^{56}$ All enzymes and chemicals were obtained from Sigma Chemical Co (St Louis, USA). Bacterial cells and spent culture supernatant were separated by centrifugation $\left(20000 \mathrm{~g}, 1 \mathrm{~h}\right.$ at $\left.4^{\circ} \mathrm{C}\right)$. Bacterial cells and spent broth culture supernatant or spent broth culture supernatant alone were incubated with trypsin $\left(2.5 \mathrm{mg} \mathrm{ml}^{-1}\right)$ for 60 minutes at $37^{\circ} \mathrm{C}$; trypsin was inactivated by adding inactivated $\left(30 \mathrm{~min}, 56^{\circ} \mathrm{C}\right)$ fetal bovine serum (Boehringer, Mannheim, Germany). To determine the influence of calcium on adherence of $L$ acidophilus, ${ }^{3}$ the monolayers were washed five times with the calcium chelating agent [ethylene-bis-(oxyethylenenitrilo)] tetraacetic acid (EGTA $20 \mathrm{mM}$ ) in phosphate buffered saline after the incubation period with bacteria.

\section{SCANNING ELECTRON MICROSCOPY}

For scanning electron microscopy, the tissue culture cells were grown on glass coverslips. After the bacterial adhesion assay, cells were fixed with $2.5 \%$ glutaraldehyde in $0.1 \mathrm{M}$ phosphate buffer ( $\mathrm{pH} 7 \cdot 4)$ for one hour at room temperature. After two washes with phosphate buffer, cells were postfixed for $\mathbf{3 0}$ minutes with $2 \% \mathrm{OsO}_{4}$ in the same buffer, washed three times with phosphate buffer, dehydrated in a graded series $(30 \%, 50 \%, 70 \%, 80 \%, 90 \%, 100 \%)$ of ethanol, and passaged through in a graded series $(50 \%, 70 \%, 90 \%, 100 \%)$ of amyl acetate. Cells were dried in a critical point dryer (Balzers CPD030), and coated with gold. The specimens were then examined with a Jeol JSM 25 S scanning electron microscope.

\section{ADHESION AND INVASION INHIBITION ASSAY}

Before the adhesion and invasion inhibition assays, the Caco- 2 monolayers were washed twice with phosphate buffered saline.

To determine Caco- 2 cell associated bacteria (adhering and invading bacteria) radiolabelled bacteria were used. Bacteria were suspended in the culture medium and $1 \mathrm{ml}\left(10^{8} \mathrm{CFU}\right.$ cells $\left./ \mathrm{ml}\right)$ of this suspension was added to each well of the tissue culture plates. For ETEC, DAEC, and EPEC, incubations were conducted in the presence of $1 \% \mathrm{D}$-mannose that inhibits adhesion mediated by type 1 pili. The plates were incubated at $37^{\circ} \mathrm{C}$ in $10 \% \mathrm{CO}_{2} / 90 \%$ air, 60 minutes for ETEC, DAEC, and Salmonella, 180 minutes for EPEC. The monolayers were then washed three times with sterile phosphate buffered saline. Cell associated bacteria and intestinal cells were dissolved in a $0.2 \mathrm{~N} \mathrm{NaOH}$ solution. The 
TABLE I Adhesion of Lactobacillus acidophilus strains onto human intestinal epithelial Caco-2 cells in culture. Determination of calcium dependent and independent bindings

\begin{tabular}{lll}
\hline & \multicolumn{2}{l}{ Adhesion } \\
\cline { 2 - 3 } Lactobacilli strains & Without EGTA & With 20 mM EGTA \\
\hline L acidophilus LA 1 & $155(26)$ & $63(5)$ \\
Lacidophilus LA 3 & $66(21)$ & $18(9)$ \\
L acidophilus LA 10 & $18(3)$ & $4(2)$ \\
Lacidophilus LA 18 & $23(7)$ & $5(3)$ \\
\hline
\end{tabular}

*Adhesion of lactobacilli strains onto monolayers of differentiated Caco-2 cells is expressed as a mean number (SEM) of lactobacilli adhering to the cell monolayer/100 Caco-2 cells. Twenty adhering to the cell monolayer/100 Caco-2 cells. Twenty randomised microscopic fields/cover slip were counted. Each adherence assay was conducted in triplicate with three successive Caco-2 cell passages. $\mathrm{EGTA}=($ Ethylene-bis- $($ oxyethylenenitrilo $))$ tetraacetic acid.

rate of bacterial adhesion was evaluated by liquid scintillation counting.

Bacterial internalisation was assessed by quantitative determination of bacteria located within the Caco-2 cells using unlabelled bacteria and an aminoglycoside antibiotic. Bacteria were suspended in the culture medium and $2 \mathrm{ml}\left(10^{8}\right.$
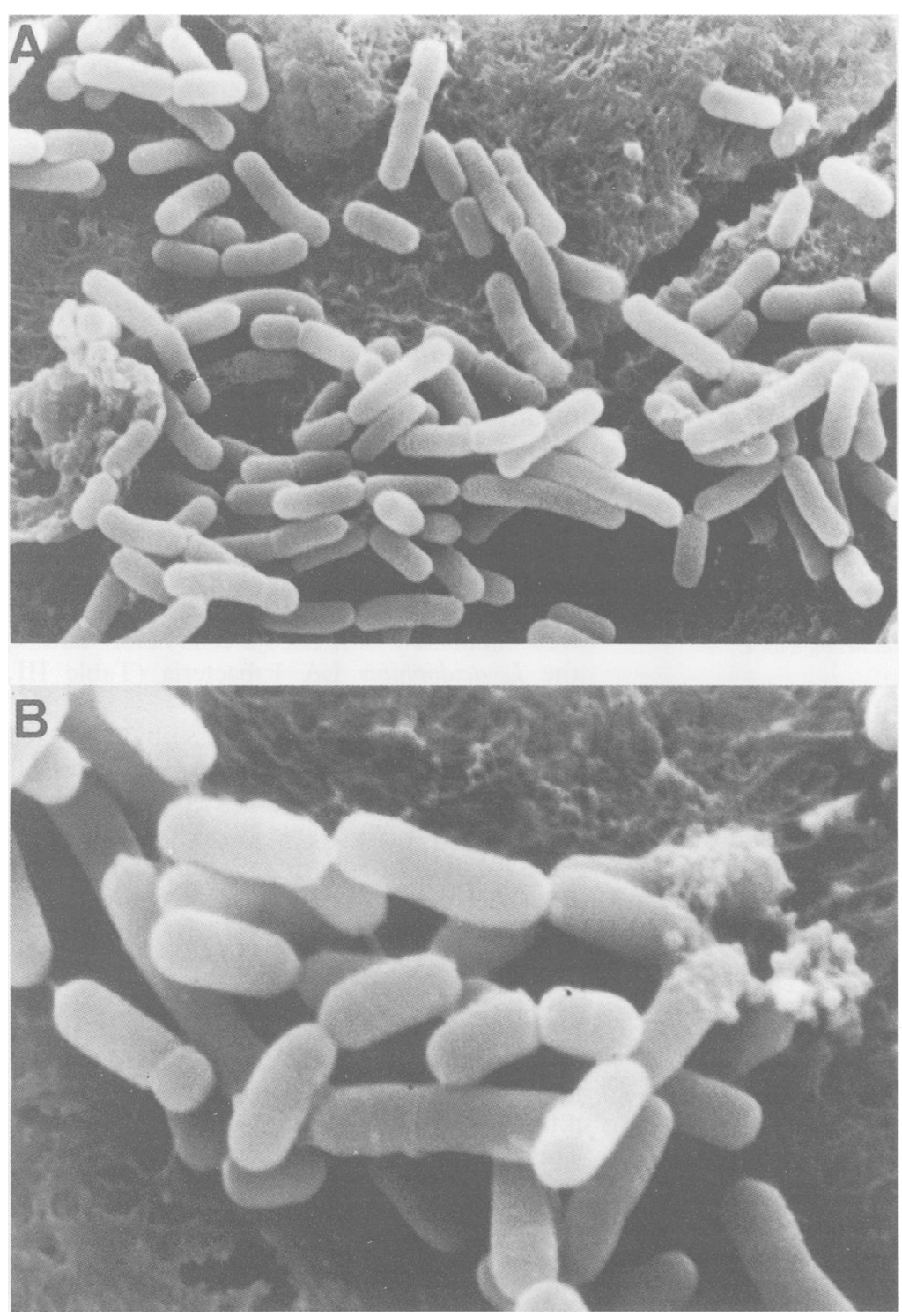

Figure 1: Examination by scanning electron microscopy of adherence of Lactobacillus acidophilus strain 1 onto the differentiated human intestinal epithelial cells Caco-2. (A) Low magnification of Caco-2 monolayer covered by $\mathrm{L}$ acidophilus 1 bacteria; $(B) \mathrm{High}$ magnification of $\mathrm{L}$ acidophilus 1 whole cells.
$\mathrm{CFU} / \mathrm{ml}$ ) of this suspension were added to each well of the tissue culture plate. The plates were incubated at $37^{\circ} \mathrm{C}$ in $10 \% \mathrm{CO}_{2} / 90 \%$ air, 180 minutes for EPEC, 90 minutes for Yersinia, and 60 minutes for Salmonella. For Yersinia, contact with Caco- 2 cells was increased by centrifugation for 10 minutes at $123 \mathrm{~g}$. After incubation the plates were washed five times with sterile phosphate buffered saline and then incubated for 120 minutes in a medium containing $20-100 \mu \mathrm{g}$ of gentamicin $/ \mathrm{ml}$. As gentamicin does not diffuse across apical domain of Caco- 2 cells, bacteria that adhere to the Caco-2 brush border were rapidly killed, whereas those located within Caco- 2 cells were not. The monolayer was washed with phosphate buffered saline and lysed with sterilised water. Appropriate dilutions were plated to determine the number of viable intracellular bacteria.

Inhibition of adhesion or invasion of pathogens by lactobacilli were evaluated as previously described. ${ }^{29}$ Briefly, $1 \mathrm{ml}$ of radiolabelled pathogenic bacteria (adhesion and invasion) or unlabelled bacteria (invasion) $\left(10^{8} \mathrm{CFU} / \mathrm{ml}\right)$ and $1 \mathrm{ml}$ of $L$ acidophilus with spent culture supernatant $\left(10^{9}\right.$ to $10^{7} \mathrm{CFU} / \mathrm{ml}$ as indicated) were added together to each well of the tissue culture plate and incubated as previously described. Each assay was conducted in triplicate with three successive passages of Caco- 2 cells.

\section{Results}

ADHESION OF L ACIDOPHILUS STRAINS TO HUMAN CULTURED INTESTINAL CELL LINES AND CHARACTERISTICS OF ADHESION

Four human Lactobacillus acidophilus strains were examined for their ability to adhere to cultured enterocyte like Caco- 2 cells (Table I). $L$ acidophilus LA 1 and LA 3 possessed a high calcium independent capacity of adhesion, whereas low capacities were expressed by $L$ acidophilus LA 10 and LA 18 strains. This result agrees with a previous finding showing that adhesive properties vary considerably between lactobacilli strains. ${ }^{6}$ As seen by scanning electron microscopy, the LA 1 strain showed diffuse adhesion to Caco-2 cells (Fig 1), as do other adhering $L$ acidophilus strains. ${ }^{56}$ Because, in the human intestine, two main cell phenotypes - that is, enterocytes and goblets cells - are represented, we examined the binding of LA 1 strain to human mucus secreting intestinal cells in culture. $L$ acidophilus LA 1 strongly bound in a diffuse pattern to the mucus secreted by the homogeneous subpopulation of HT29-MTX cells (Fig 2 ). The rate of adhesion of LA 1 whole cells to mucus secreting cells and to the mucus layer seemed higher than adhesion to enterocyte like Caco- 2 cells.

As recently seen, adhering lactobacilli strains secrete extracellular adhesions to attach to human $^{56}$ and murine ${ }^{30}$ intestinal cells. In an attempt to identify the components participating in adhesion of $L$ acidophilus LA 1 to human intestinal cells in culture, we subjected the LA 1 culture to several treatments (Table II). When the spent culture supernatant was discarded and replaced by a fresh culture medium, a dramatic 

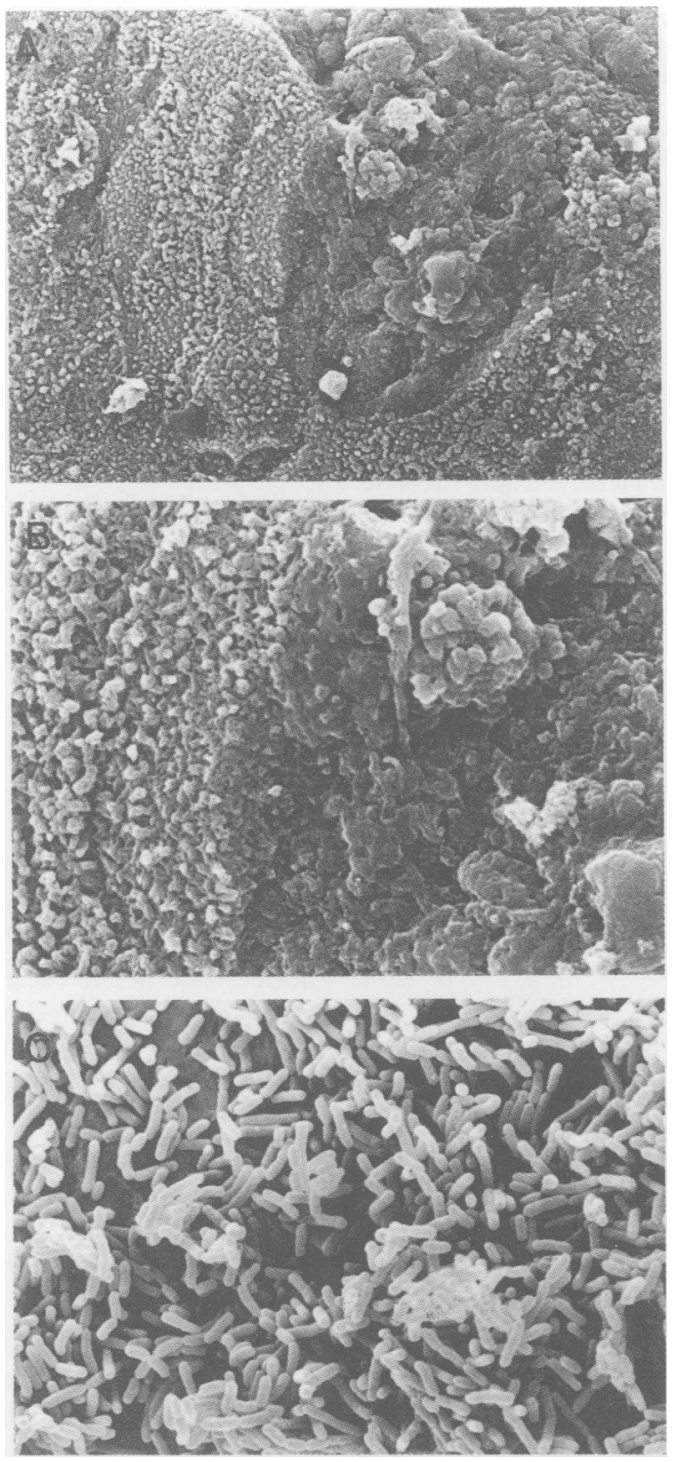

Figure 2: Adhesion of Lactobacillus acidophilus strain 1 to mucus secreting HT29-MTX monolayer seen by low and high magnification scanning electron microscopy. $(A)$ and $(B)$ Low and high magnification of HT-29 cell monolayer. Notice that brush border of the HT29-MTX cells is not visible because it is entirely covered by the dense mucus gel; (C) Observation of high level of adhesion with $\mathrm{L}$ acidophilus strain 1 .

loss of adhesion occurred. Trypsin treatment of the spent culture supernatant totally abolished the adhesive capacity of $L$ acidophilus LA 1 . These results show that an extracellular proteinaceous component secreted in the bacterial spent culture supernatant participates in the adhesion of LA 1 to intestinal cells.

INHIBITION OF PATHOGENS CELL ASSOCIATION AND CELL INVASION WITH AND WITHIN CACO-2 CELLS BY L ACIDOPHILUS LA 1

Diarrhoeagenic Escherichia coli ${ }^{14161831}$ and Salmonella typhimurium ${ }^{17}$ interact with the brush border of differentiated cultured human intestinal cell lines. By contrast, Yersinia pseudotuberculosis interacts only with cell periphery of undifferentiated Caco-2 cells (A Servin et al, unpublished data), as does Listeria monocytogenes. ${ }^{19}$

We examined the inhibition of cell association
TABLE II Characteristics of adhesion of Lactobacillus acidophilus $L A 1$ strain

\begin{tabular}{llc}
\hline & & Adhesion score \\
\hline Adhesions: & With spent culture supernatant & $124(13)$ \\
& With fresh culture medium ${ }^{\star}$ & $9(3)$ \\
& Trypsin $\dagger$ & 0.6
\end{tabular}

Adhesion is expressed as a mean number (SEM) of lactobacilli adhering to the cell monolayer $/ 100 \mathrm{Caco}-2$ cells, determined in 20 randomised microscopic fields/cover slip. Each adherence assay was conducted in triplicate with three successive Caco- 2 cell passages. ${ }^{\star}$ To determine the presence of adhesive factors secreted $b y$ the bacteria in the spent culture supernatant, it was replaced
by a fresh by a fresh culture medium before adhesion assay; $†$ To f

characterise the bacterial determinants participating in $L$ acidophilus $\mathrm{LA} 1$ adhesion, bacteria with spent broth culture
supernatant was subjected to trypsin treatment $(2.5 \mathrm{mg} / \mathrm{ml})$ for supernatant was subjected to trypsin treatment $(2.5 \mathrm{mg} / \mathrm{ml})$ for
$60 \mathrm{~min}$ at $37^{\circ} \mathrm{C}$, then trypsin was inhibited by adding inactivated $\left(30 \mathrm{~min}, 56^{\circ} \mathrm{C}\right)$ fetal bovine serum.

and cell entry of several enterovirulent bacteria by $L$ acidophilus LA 1 (Tables III and IV, and Fig 3). By using radiolabelled bacteria $\left(10^{8} \mathrm{CFU} / \mathrm{ml}\right)$, we evaluated the cell association (adhering and invading bacteria) of enterotoxigenic (ETEC CFA/I), diffusely adhering (DAEC C-1845), and enteropathogenic (EPEC JPN15 [pMAR7]) $E$ coli, and $S$ typhimurium (SL 1344) strains with Caco-2 cells. The bacterial entry of these EPEC, $S$ typhimurium, and $Y$ pseudotuberculosis (YPIII [pYV ${ }^{-}$) strains into Caco-2 cells was measured using unlabelled bacteria $\left(10^{8} \mathrm{CFU} / \mathrm{ml}\right)$ and gentamicine, which selectively kills the noninternalised bacteria.

$L$ acidophilus LA 1 strain efficiently inhibited cell association of these ETEC, DAEC, EPEC, and $S$ typhimurium strains with Caco-2 cells in a dose dependent fashion (Fig 3). For all pathogens, $50 \%$ inhibition of cell association was obtained with $10^{8}$ lactobacilli/ml. We examined different conditions of bacterial incubation to further characterise the inhibitory action of $L$ acidophilus LA 1 (Table III). When LA 1 organisms were incubated with Caco- 2 cells before the infection with ETEC or together with ETEC, an identical inhibition of $E$ coli cell association was seen. By contrast, a significant decrease of efficacy was seen when the pathogens were incubated with Caco-2 cells before adding the $L$ acidophilus LA 1 bacteria (Table III, $\mathrm{p}<0.01$ ).

Invasion of Caco-2 cells by selected $Y$ pseudotuberculosis, $S$ typhimurium, and EPEC strains was inhibited in a dose dependent way by $L$ acidophilus LA 1 (Table IV). This strain at $10^{8}$ $\mathrm{CFU} / \mathrm{ml}$ inhibited more efficiently Caco-2 cells invasion by EPEC and $Y$ pseudotuberculosis, than that by $S$ typhimurium.

\section{Discussion}

As previously reported, the polarised human intestinal epithelial cells Caco-2 could be used to promote the selection of Lactobacillus strains. ${ }^{256}$ This stable and reproducible model permits evaluation of the comparative adherence capacities of these strains in the human intestine, a property that is thought to be essential for intestinal maintenance or colonisation. Moreover, this model provides an excellent system to characterise the manner by which lactobacilli interact with a well defined enterocytic brush border. ${ }^{56}$ Among the four human $L$ acidophilus 
TABLE III Competitive inhibition of attachment of diarrhoeagenic Escherichia coli to Caco-2 cells by preincubation or postincubation of the cell monolayers with $\mathrm{L}$ acidophilus $L A \mid 1$

\begin{tabular}{|c|c|c|}
\hline Condition & $\begin{array}{l}\text { ETEC CFA/I } \\
\text { (\% of inhibition) }\end{array}$ & $\begin{array}{l}\text { DAEC C-F1845 } \\
\text { (\% of inhibition) }\end{array}$ \\
\hline $\begin{array}{l}\text { Incubation together with } L \text { acidophilus LA } 1^{\star} \\
\text { Preincubation of } L \text { acidophilus LA } 1 \dagger \\
\text { Postincubation of } L \text { acidophilus LA i }\end{array}$ & $\begin{array}{l}80(9) \\
77(7) \\
22(3) \bigvee\end{array}$ & $\begin{array}{l}85(8) \\
81(3) \\
45(5) \emptyset\end{array}$ \\
\hline
\end{tabular}

*Caco-2 cell monolayers were incubated with labelled $E$ coli $\left(10^{8} \mathrm{CFU} / \mathrm{ml}\right)$ together with $L$ acidophilus $\mathrm{LA} 1\left(5 \times 10^{8} \mathrm{CFU} / \mathrm{ml}, 37^{\circ} \mathrm{C}\right.$ in $10 \% \mathrm{CO} / 90 \%$ air, $\left.60 \mathrm{~min}\right)$. +Caco-2 cell monolayers were first incubated for 30 minutes with $L$ acidophilus $\mathrm{LA} 1\left(10^{8} \mathrm{CFU} / \mathrm{ml}, 37^{\circ} \mathrm{C}\right.$ in $10 \% \mathrm{CO}_{2} 90 \%$ air $)$, and then infected with labelled $E$ coli $\left(10^{8} \mathrm{CFU} / \mathrm{ml}, 60 \mathrm{~min}\right)$. $¥$ Caco- 2 cell monolayers were first infected 政 $\left(5 \times 10^{8} \mathrm{CFU} / \mathrm{ml}, 60 \mathrm{~min}\right)$. Each experiment was conducted in triplicate. The data represent mean values (SEM) of experiments from three successive passages of Caco-2 cells. \Significant difference $(\mathrm{p}<0 \cdot 01)$. ETEC=enterotoxigenic $E$ coli , DAEC=diffusing adhering $E$ coli.

TABLE IV Inhibition of cell invasion by enterovirulent bacteria within Caco-2 cells, with adherent $\mathrm{L}$ acidophilus $L A I$

\begin{tabular}{llll}
\hline & $\begin{array}{l}\text { EPEC } \\
\mathcal{F P N I 5}[p M A R 7]\end{array}$ & $\begin{array}{l}\text { Ypseudotuberculosis } \\
\text { YPIII [pYV] }\end{array}$ & $\begin{array}{l}\text { Styphimurium } \\
S L 1344\end{array}$ \\
\hline $\begin{array}{l}\text { Cell invasion } \\
\text { (\% of incubated bacteria) }\end{array}$ & $1 \cdot 5(0 \cdot 4)$ & $8 \cdot 5(0 \cdot 9)$ & $8 \cdot 0(3 \cdot 0)$ \\
$\begin{array}{c}\text { Inhibition of cell invasion } \\
\text { (\% of inhibition) } \\
10^{8} \mathrm{CFU} / \mathrm{ml}\end{array}$ & & & \\
$10^{7} \mathrm{CFU} / \mathrm{ml}$ & $95(2)$ & $64(19)$ & $37(4)$ \\
\hline
\end{tabular}

Invaded bacteria within Caco- 2 cells were measured after incubating unlabelled bacteria at $37^{\circ} \mathrm{C}$ in $10 \% \mathrm{CO}_{2} / 90 \%$ air, 60 minutes for $S$ typhimurium, 90 minutes for $Y$ pseudotuberculosis, and 180 minutes for EPEC. The monolayer was then washed three times with sterile phosphate buffered saline and incubated 120 minutes in a medium containing $20-100 \mu \mathrm{g}$ of gentamicin/ml to kill extrallular bacteria, all at $10^{8} \mathrm{CFU} / \mathrm{ml}$. Invasion was measured using undifferentiated Caco-2 cells

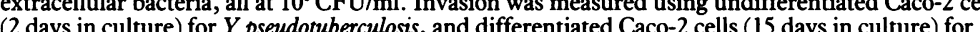
(2 days in culture) for $Y$ pseudotuberculosis, and differentiated Caco-2 cells ( 15 days in culture) for EPEC and $S$ typhimurium. Each experiment was conducted in triplicate. The data repres
values $(\mathrm{SEM})$ of experiments from three successive passages of Caco-2 cells. EPEC= enteropathogenic $E$ coli. intestinal colonisation and in consequence modify the process of pathogenicity. Inhibition of cell association of enterotoxigenic $E$ coli by adhering $L$ acidophilus $\mathrm{LB},{ }^{29}$ and inhibition of cell association with and cell invasion within Caco-2 cells of enterovirulent pathogens obtained with LA 1 strain seems in terms of efficacy comparable with inhibitions obtained with lectins, ${ }^{31}$ carbohydrate complexes, ${ }^{334}$ and other biological compounds..$^{35}$ In the normal mucosa, the endogeneous microflora protects the mucosa against attachment of pathogens by a 'barrier effect'. Lactobacilli inhibit adhesion of pathogens in animal ${ }^{36}$ and in non-intestinal in vitro ${ }^{36}{ }^{37}$ models. Reid et al explain the inhibitory effect of lactobacilli by a non-specific steric hindrance of the receptors for pathogens. ${ }^{36}$ The mechanism of competitive exclusion of pathogens by $L$ acidophilus LA 1 seems to be a result of a nonspecific steric hindrance rather than to a specific blockage of receptors sites, as LA 1 can protect intestinal cells against attachment and invasion of a large variety of enterovirulent bacteria. By contrast, each pathogen has a specific intestinal receptor, and enteroinvasive bacteria have developed very different pathways for entry into the cells. ${ }^{32}$

Adherent Lactobacillus seems to be crucial in the preparations of intestinal probiotics or dietary adjuncts. Use of inhabitants of normal
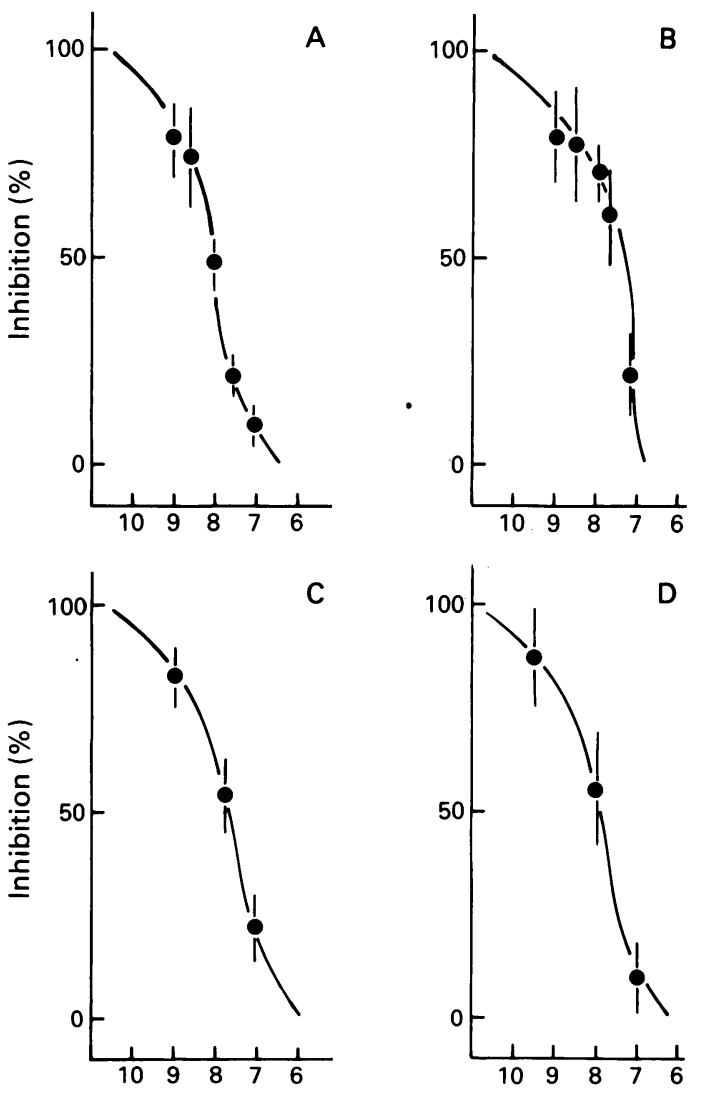

Log CFU/ml

a close association with the intestinal mucosa, which is the first step of bacterial infection and initiation of infectious diseases. For example, close association of invading bacteria with the brush border promotes brush border lesions, permits cell entry and after bacterial proliferation promotes cell death and exfoliation. Inhibiting the attachment of pathogenic bacteria to their brush border binding sites could decrease the
Figure 3: Competitive exclusion of diarrhoeagenic bacteria from human enterocyte like Caco-2 cells in culture by increasing concentrations of Lactobacillus acidophilus strain LA $1(\log C F U / m l)$. (A) Enterotoxigenic H10407, $(B)$ diffusely adhering $C-1845$, (C) enteropathogenic JPN15 [pMAR7] Escherichia coli, and (D) S typhimurium $S L$ 1344 strains $\left(10^{8} \mathrm{CFU} / \mathrm{ml}\right.$ each). Each experiment was conducted in triplicate. The data represent mean values of experiments from three successive passages of Caco-2 cells. 
human microflora, such as lactobacilli and bifidobacteria, in fermented milk products could aid in preventing intestinal infections. Although controversial, ${ }^{78}$ the protective role of lactobacilli against intestinal colonisation by pathogenic bacteria has recently gained more credibility. Consistent findings using well characterised intestinal cell models ${ }^{2-629}$ have brought insights on the action of lactobacilli. Indeed, reports show that adhering lactobacilli survive in the human stomach $^{38}$ and that the adherent $L$ casei GG strain ${ }^{2}$ used in fermented milk products is maintained in the human intestine after oral administration. ${ }^{39}$ Moreover, recent controlled clinical studies have produced convincing evidence concerning the beneficial effects of adherent lactobacilli. ${ }^{40}$ In this report, we found that in vitro incubation of $L$ acidophilus before infection with pathogens provided an important inhibition of pathogen attachment, similar to that obtained by incubation of pathogens together with $L$ acidophilus. By contrast, when the infection of the intestinal Caco-2 cell monolayers by pathogens came before the incubation of $L$ acidophilus, a decrease of efficacy occurs. This result strongly suggests a preventive role of lactobacilli against intestinal infections.

In conclusion, the results presented here clearly show that $L$ acidophilus LA 1 inhibits the cell association and the cell entry of some enteropathogens present in diarrhoea. The precise mechanism, however, for the inhibitory effect of the Lactobacillus has not been fully clarified. It could result from (a) the non-specific steric hindrance of the apical enterocytic receptors of pathogens by the Lactobacillus whole cells, (b) the antimicrobial action of a Lactobacillus secreted molecule with a large spectre of action (bacteriocin like activity), (c) the stimulation of secretion by intestinal cells of an antimicrobial substance (defensin like activity), after $L a c$ tobacillus cell binding. Further experiments are required to elucidate the nature of the mechanism(s) of this event.

This work was supported by a grant INSERM-Industrie $\mathrm{N}^{\circ}$ 90025. MFB is supported by a doctoral fellowship of Ministère de la Recherche, de la Technologie et de l'Espace. We thank A Zweibaum (INSERM U 178, Villejuif, France) for providing us Zweibaum (INSERM U 178, Villejuif, France) for providing us with Caco-2 and HT29-MTX cell lines. We thank D Guillaumin
(Service Microscopie Electronique, CNRS Université Pierre et (Service Microscopie Electronique, CNRS Université Pierre et
Marie Curie Paris VI) for the technical assistance with the electron microscopy study.

1 Klaenhammer TR. Microbial considerations in selection and preparation of Lactobacillus strains for use as dietary preparation of Lactobacillus strains

2 Elo S, Salminen S. Attachment of Lactobacillus casei strain GG to human colon carcinoma cell line Caco-2: comparison with to human colon carcinoma cell line Caco-2: comparison

3 Kleeman EG, Klaenhammer TR. Adherence of Lactobacillus species to human fetal intestinal cells. $\mathcal{F}$ Dairy Sci 1982; 65 2063-9.

4 Hood SK, Zottola EA. An electron microscopic study of the adherence of Lactobacillus acidophilus to human intestinal cells in vitro. Food Microstructure 1989; 8: 91-7.

5 Coconnier MH, Klaenhammer TR, Kernéis S, Bernet MF, Servin AL. Protein-mediated adhesion Lactobacillus acidophilus strain BG2FO4 on human enterocyte and mucus-secreting cell lines in culture. Appl Environ Microbiol 1992; 58: 2034-9.

6 Chauvière G, Coconnier MH, Kernéis S, Fourniat J, Servin AL. Adherence of human Lactobacillus acidophilus onto human enterocyte-like cells, Caco-2 and HT-29 in culture. f Gen Microbiol 1992; 138: 1689-96.

7 Conway P. Lactobacilli: Fact and fiction. In: Grun R, Midvedt $\mathrm{T}$, Norin $\mathrm{E}$, eds. The regulatory and protective role of the normal $\mathrm{T}$, Norin E, eds. The regulatory and prote
flora. Stockton Press, 1988: 263-81.

8 Reid G, Bruce AW, McGroarty JA, Cheng KJ, Costerton JW. Is there a role for Lactobacilli in prevention of urogenital and Fogh J, Fogh JM, Orfeo T. One hundred and twenty seven cultured human tumor cell lines producing tumors in nude mice. F Natl Cancer Inst 1977; 59: 221-6.

10 Pinto M, Robine-Leon S, Appay MD, Kedinger M, Triadou $\mathrm{N}$, Dussaulx E, et al. Enterocyte-like differentiation and polarization of the human colon carcinoma cell line Caco-2 in polarization of the human colon carcin

11 Zweibaum A, Laburthe M, Grasset E, Louvard D. Use of cultured cell lines in studies of intestinal cell differentiation and function. In: Schultz SJ, Field M, Frizell RA, eds. and function. In: Schultz SJ, Field M, Frizell RA, eds. Handbook of physiology. The gastrointestinal system vol IV.

2 Louvard D, Kedinger M, Hauri HP. The differentiating intestinal epithelial cell: establishment of functions through interactions between cellular structures. Annu Rev Cell Biol 1992; 8: 157-95.

13 Aubel D, Darfeuille-Michaud A, Joly B. New adhesive factor (Antigen 8786) on a human enterotoxigenic Escherichia coli O117:H4 strain isolated in Africa. Infect Immun 1991; 59: 1290-9.

14 Darfeuille-Michaud A, Aubel D, Chauvière G, Rich C, Bourges M, Servin A, et al. Adhesion of enterotoxigenic Escherichia coli to the human colon carcinoma cell line Escherichia coli to the human colon carcinoma

15 Kernéis S, Bilge S, Fourel V, Chauvière G, Coconnier MH, Servin AL. Use of purified F1845 fimbrial adhesin to study localization and expression of receptors for diffusely adhering Escherichia coli (DAEC) during enterocytic differentiation of human colon carcinoma cell lines HT-29 and Caco-2 in culture. Infect Immun 1991; 59: 4013-8.

16 Kernéis S, Chauvière G, Darfeuille-Michaud A, Aubel D, Coconnier MH, Joly B, et al. Expression of receptors of enterotoxigenic Escherichia coli during enterocytic differenenterot of HT-29, in culture. Infect Immun 1992; 60: 2572-80.

17 Finlay BB, Falkow S. Salmonella interactions with polarized human intestinal Caco-2 epithelial cells. F Infect Dis 1990; 162: 1096-106.

18 Francis CL, Jerse AK, Kaper JB, Falkow S. Characterization of interactions of enteropathogenic Escherichia coli O127:H6 with mammalian cells in vitro. F Infect Dis 1991; 164: 693-703.

19 Gaillard JL, Berche P, Mounier J, Richard S, Sansonetti JP. In vitro model of penetration and intracellular growth of Listeria monocytogenes in the human enterocyte-like cell line Caco-2. Infect Immun 1987; 55: 2822-9.

20 Mounier J, Vasselon T, Hellio R, Lesourd M, Sansonetti PJ. Shigella flexneri enters human colonic Caco-2 epithelial cell through the basolateral pole. Infect Immun 1992; 60: 237-48.

21 Svensson L, Finlay BB, Bass D, Vonbonsdorff CH, Greenberg HB. Symmetric infection of rotavirus on polarized human intestinal epithelial Caco-2 cells. F Virol 1991; 65: 4190-7.

22 Rubino A. Secretory diarrhea in infants and children. In: Lebenthal $\mathrm{E}$, ed. Textbook of gastroenterology and nutrition in infancy. New York: Raven Press, 1989: 1159-70.

23 Okhuysen PC Ericson CD. Travelers' diarrhea. Travel Medicine 1992; 76: 1357-73.

24 Evans DG, Evans Jr DJ, Clegg S, Pauley JA. Purification and characterization of the CFA/I antigen of enterotoxigenic Escherichia coli. Infects Immun 1987; 25: 738-48.

25 Bilge SS, Clausen CR, Lau W, Moseley SL. Molecular characterization of a fimbrial adhesin, F1845, mediating diffuse adherence of diarrhea-associated Escherichia coli to HEp-2 cells. F Bacteriol 1989; 171: 4281-9.

26 Giron JA, Jones T, Millan-Velasco F, Castro-Munoz E, Zarate L, Fry J, et al. Diffuse-adhering Escherichia coli (DAEC) as a putative cause of diarrhea in Mayan children in Mexico. a putative cause of diarrhea in
Infect Dis 1991; 163: 507-13.

27 Isberg RR, Voorhis DL, Falkow S. Identification of invasin: A protein that allows enteric bacteria to penetrate cultured protein that allows enteric bacteria to

28 Lesuffleur T, Barbat A, Dussaulx E, Zweibaum A. Growth adaptation to methotrexate of HT-29 human colon carcinoma cells is associated with their ability to differentiate into columnar absorptive and mucus-secreting cells. Cancer Res 1990; 50: 6334-43.

29 Chauvière G, Coconnier MH, Kernéis S, Darfeuille-Michaud A, Joly B, Servin AL. Competitive exclusion of diarrheagenic Escherichia coli (ETEC) from enterocyte-like Caco-2 cells in culture. FEMS Microbiol Lett 1992; 91: 213-8.

30 Conway PL, Kjelleberg S. Protein-mediated adhesion of Lactobacillus frementum strain 737 to mouse stomach Lactobacillus frementum strain 737 to mouse stomach
squamous epithelium. F Gen Microbiol 1989; 135: 1175-86.

31 Neeser JR, Chambaz A, Golliard M, Link-Amster H, Fryder $\mathrm{V}$, Kolodziejczyk E. Adhesion of colonization antigen factor antigen II-positive enterotoxigenic Escherichia coli strains to human enterocyte-like differentiated HT-29 cells: a basis for host-pathogen interactions in the gut. Infect Immun 1989; 57 ; 3727-34.

32 Falkow S, Isberg RR, Portnoy DA. The interaction of bacteria with mammalian cells. Annu Rev Cell Biol 1992; 8: 333-63.

33 Neeser JR, Chambaz A, Hoang KY, Link-Amster H. Screening for complex carbohydrates inhibiting hemagglutinations by CFA/I- and CFA/II-expressing enterotoxingenic Escherichia coli strains. FEMS Microbiol Lett 1988; 49: 301-7.

34 Cravioto A, Tello A, Villajan H, Ruiz J, del Vedovo S, Neeser JR. Inhibition of localized adhesion of enteropathogenic
Escherichia coli to $\mathrm{HEp}-2$ cells by immunoglobulin of oligosaccharide fractions of human colostrum and breast oligosaccharide fractions of human
milk. F Infect Dis 1991; 163: 1247-55.

35 Reid G, Cook RL, Bruce AW. Examination of strains of lactobacilli for properties that may influence bacterial interference in the urinary tract. $F$ Urol 1987; 138: 330-5. 
36 Gotteland M, Pochart P, Dabbech M, Bisetti N, Desjeux JF In vivo effect of yogurt on excretion of enteropathogen Escherichia coli RDEC-1 during acute diarrhea in the justweaned rabbit. F Pediat Gastroenterol 1992; 14: 264-7.

37 Blomberg L, Henriksson A, Conway PL. Inhibition of adhesion of Escherichia coli K88 to piglet ileal mucus by Conway PL, Gorbach SL, Goldin BR. Survival of lactic acid bacteria in the human stomach and adhesion to intestinal cells. F Dairy Sci 1987; 70: 1-12.

39 Goldin BR, Sherwood L, Saxelin M, Barakat S, Gualteri L, Salminen S. Survival of Lactobacillus species (Strain GG) in human gastrointestinal tract. Dig Dis Sci 1992; 37: 121-8.

40 Isolauri E, Juntunen M, Rautanen T, Sillanaukee P, Koivula TA. A human Lactobacillus strain (Lactobacillus casei sp strain GG) promotes recovery from acute diarrhea in children. Pediatrics 1991; 88: 90-7. 